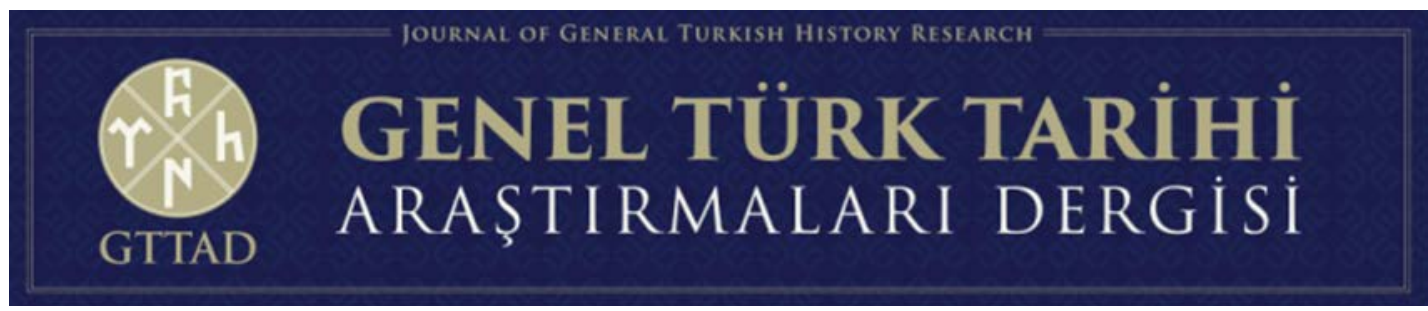

Cilt/Volume 3, Sayı/Issue 6, Temmuz/July 2021, ss. 283-292.

Geliş Tarihi-Received Date: 23.02.2021 Kabul Tarihi-Accepted Date: 02.06.2021

ARAŞTIRMA MAKALESI - RESEARCH ARTICLE

İHTIYAR B. GIYASÜDDIN (Ö. 928/1521): BİR TİMURLU KADISININ BIIYOGRAFİSİ

ÖZ

\title{
ERTUĞRUL ÖKTEN*
}

Timurlu tarihinde toplumdaki etkileri, eseriyle dikkat çekici birçok şahsiyet bulunmaktadır. Bunlardan bir tanesi Herat kadısı olarak bilinen İhtiyar b. Gıyasüddin'dir (ö. 1521). Tarihte birçok eseriyle iz bırakan İhtiyar Muhtar el-İhtiyar adlı eseri ile Timurlu kaza dünyası hakkında fikir verirken, Zinetü'l-libas ile gününün giyim kültürüne, Şerh-i Kaside-yi Cami adlı eseri ile de Herat entelektüel dünyasına 1şık tutar. En bilinen eseri olan Esasü'l-İktibas adlı inşa kitabı onun Nevai (ö. 1501)-Cami (ö. 1492) çevresinin bir üyesi olduğunu açıkça gösterir. Bu çalışmanın hedefi kaynaklarda bulunan bilgileri bir araya getirerek basit bir biyografik portre oluşturmak ve böylece İhtiyar'ı tarihsel çalışmanın nesnesi haline getirmektir.

Babası kadı olan İhtiyar b. Gıyasüddin Horasan'ın Zave şehrindendi. Gençliğinde Herat'a geldi. Herat’ta aldığı eğitimden sonra kaza alanına girdi. 1490’larda Kadı Nizamüddin’in (ö. 1495) mahkemesinde çalıştı. Kadı Nizamüddin mahkemesinde belge düzenleme işi bu alandaki kabiliyetinden dolayı ona verildi. Sultan-Hüseyin Baykara (ö. 1506) devrinin sonlarında Herat kadısı olduğunu bilinmektedir. Bir mahkemeden başlayıp şehrin kadılığına kadar yükselmesi kaza alanından hiç uzaklaşmadığını düşündürür. Kazanın aile geleneği olması bu alana girmesini ve yükselmesini kolaylaştırmış olmalıdır. Ayrıca daha 1490'larda fikıh bilgisi ile ün kazanmasında da yine babasından gelen hukuk birikiminin payı olması yüksek bir ihtimaldir. 1500'lerin başında Nevai Medresesi'nde müderrislik de yapmıştır. İhtiyar bir şair olarak da Herat'ta görünür bir kişi haline geldi. 1490'ların ve 1500'lerin başında belli mimari eserler için düşürdüğü tarihler onu kamusal alanda daha görünür k1ld1.

Şehri temsil ya da şehir adına karar verme pozisyonunda olanlardan biri haline gelen İhtiyar Herat'ın Özbek Şeybani Han'a (ö. 1510) teslimine (1507) karar verenlerden biriydi. Bu hareketi ile Timurlu idaresinden Özbek idaresine geçişi kolaylaştırdığı düşünülebilir. Kadılık pozisyonunu kaybetmemesine bakılırsa kendisi de yeni idareye uyum sağlamıştır. Safevilerin 1510'da Herat'1 ele geçirmeleri ise talihini tersine çevirmiş görünüyor. Ömrünün sonuna doğru memleketi olan Zave'ye çekildi ve orada öldü. Kendisinden sonra oğlu Herat'ta kadılık yapmıştır.

İhtiyar'ın hayatı Herat'ın bir eğitim, kültür merkezi olarak çevresi için çekim merkezi olması, şehrin kadı tarafından temsili, ailelerin aynı görevlere nesiller boyu sahip olmaları gibi Timurlu dünyasının bazı özelliklerini yansitir.

Anahtar Kelimeler: İhtiyar b. Gıyasüddin, Timurlu, Herat, Kadı, Biyografi, İnşa.

\section{IKHTIYAR B. GHIYATH AL-DIN (D. 928/1521): A BIOGRAPHICAL ESSAY ON A TIMURID QADI}

\section{ABSTRACT}

Timurid history is rich with figures who made an impact in the society by their actions or works. One such figure is Ikhtiyar b. Ghiyath al-din (d. 1521), also known as Qadi of Herat. Ikhtiyar left his mark in history through a number of works. For example, Mukhtar al-Ikhtiyar sheds light on the Timurid world of qada, Zinat al-Libas illuminates the clothing culture of the $15^{\text {th }}$ century, Sharh Qasida-ya Jami gives us a glimpse of the * Dr. Öğr. Üyesi, İstanbul 29 Mayıs Üniversitesi, Edebiyat Fakültesi, Tarih Bölümü, E-Posta: eiokten@gmail.com, ORCID ID: 0000-0001-
9349-2646 


\section{İHTIYAR B. GIYASÜDDIN (Ö. 928/1521): BİR TIMURLU KADISININ BIYYOGRAFİSí}

intellectual world in Herat. Asas al-Iqtibas, an insha work which became his best-known work, clearly demonstrates that Ikhtiyar was a member of the Nawai (d. 1501)-Jami (d. 1492) circle. The purpose of this article is drawing a simple biographical sketch of Ikhtiyar by bringing together the information found in the sources, and thus making him the object of historical research.

Ikhtiyar, whose father was a qadi, was from Zave, Khorasan. In his youth he moved to Herat. After completing his education in Herat, he started to work in the field of qada. In 1490's he worked in the court of Qadi Nizam al-din (d. 1495). Since he proved to be particularly talented in composing legal documents, he was given that task in the court. He became the qadi of Herat towards the end of Sultan-Husayn Bayqara's reign. His ascension to the position of the qadi of the city starting from a legal scribal position in a court makes one think that he never distanced himself from qada. Possibly, the fact that qada was a family occupation facilitated his initiation to and rise in the field of qada. His renown due to his competency in fiqh could have been a result of the legal expertise he inherited from his father. In the beginning of 1500's he served as mudarris in the madrasa of Nawai. Also, he acquired fame as a poet in Herat. Certain chronograms he composed at the beginning of 1490’s and 1500's were used as epigraphs in public buildings contributing to his public visibility.

Ikhtiyar gained a representative capacity for the city of Herat. He was among the group that decided handing over of the city to the Uzbek Shaybani Khan (d. 1510) in 1507. One can say that his role in that process facilitated the transition from the Timurid to the Uzbek rule. Since he kept his position as qadi under the Uzbek administration one can surmise that he somehow adapted himself to the new administration. Safavid conquest of Herat in 1510 changed his destiny for worse. Towards the end of his life he moved to Zave and died there. After him his son served as qadi in Herat.

Ikhtiyar's life reflects several realities of the Timurid world such as Herat being a point of attraction as a cultural and educational center, qadi representing the city, and particular families assuming the same official function in a city for generations.

Keywords: İkhtiyar b. Ghiyath al-din, Timurid, Herat, Qadi, Biography, Insha.

\section{GİRIŞ}

Timurlu tarihi çalışmalarında belli konular ve kişilerin çok vurgulandığı söylenebilir. Özellikle siyasi ve askeri tarih açısından incelenen Timur ve dönemi; daha çok siyasi ve entelektüel tarih ile sanat tarihi çalışmalarının konusu olan Şahruh (ö. 1447) ve dönemi; edebiyat ve sanat tarihi açısından incelenmekle beraber siyasi tarih açısından da ele alınan Sultan-Hüseyin Baykara (ö. 1506) ve saltanatı Timurlu tarihinin üzerine çok yoğunlaşan alanlarındandır. ${ }^{1}$ Bunlara hayatlarının en üretken kısımları Sultan-Hüseyin Baykara devrine denk düşen Nevai (ö. 1501), Cami (ö. 1492) ve Hüseyin Vaiz-i Kaşifi (ö. 1504) üzerine yapılan çalışmalar eklenebilir. $\mathrm{Bu}$ kişiler eylemleri, bıraktıkları eser ve etkiler, ya da yazılmasına sebep oldukları eserler nedeni ile Timurlu tarihinde araştırmacıların ilgisi en çok çeken kişiler olmuşlardır. Araştırmaların konular açısından çeşitlenmemesi bazı alanların ihmal edilmesi sonucunu doğurmuştur. $\mathrm{Bu}$ eksiklerden bir tanesinin entelektüel/sosyal 'çevre/muhit' araştırmaları olduğunu söyleyebiliriz. Tanımı gereği birçok kişiden oluşan 'çevre’lere 1 şı tutabilmenin bir yolu daha önce araştırılmayan kişilere yönelmek ve bunların uğraştıkları meseleleri tanımlamaya çalışmaktır.

Bu makale daha önce araştırmalarda pek dikkati çekmeyen bir Sultan-Hüseyin Baykara devri kişiliğini konu edinmektedir. Bir Timurlu münşisi, kadısı ve yazarı olan İhtiyar b. Gıyasüddin, Nevai-Cami çevresinin bir üyesi olarak görünmektedir. İhtiyar Timurlu başkenti Herat’a gelip kariyer basamaklarını tırmandıktan sonra Sultan-Hüseyin Baykara saltanatının sonlarına doğru Herat kadısı oldu. Safevilerin ve Özbeklerin Herat'ı fethine şahitlik etti. Safevi-Özbek rekabetinde Herat nihai olarak Safevilerin elinde kalınca o da artık Safevi toprağı haline gelmiş olan memleketi Zave’ye döndü ve burada öldü.

Literatürde İhtiyar'ın biyografisi üzerine kısa tespitler bulunmaktadır. ${ }^{2}$ Bu makale İhtiyar hakkındaki kaynaklarda bulunabilen bilgiyi bir araya getirerek İhtiyar'ın biyografisini oluşturmayı hedefler. İhtiyar'ın çevresinde Sultan-Hüseyin Baykara, Nevai, Cami, Hüseyin Vaiz-i Kaşifi gibi şahsiyetler vardır. İhtiyar'ın

\footnotetext{
${ }^{1}$ Sultan-Hüseyin Baykara isminde "sultan” bir unvan değil isim olduğu için yaygın olan "Sultan Hüseyin Baykara” yerine "Sultan-Hüseyin Baykara” yazımı tercih edilmiştir. "Sultan” kelimesinin Timurlularda isim olarak kullanılması hakkında bkz. John E. Woods, The Timurid Dynasty, Indiana University, Bloomington Indiana 1990, s. 25, 55. Aynı durum Sultan-Ebu Said için de geçerlidir.

2 Muhammed Hasan Simsar, "İhtiyarüddin Türbeti”, Daire-ye Bozorg-e Maarif-e İslami, C. 7, Tahran 1377/1998, s. 174, 175. Buna ek olarak Handmir'in Mekarimu'l-Ahlak'ında Aşîk'in hazırladığı notlar (talik) kısmında İhtiyar hakkında kısa bir bilgi vardır. Gıyasüddin b. Himamüddin Handmir, Mekarimu’l-Ahlak Şerh-e Ahval u Zindegani-ye Emir Alişir Nevai, haz. Muhammed Ekber Aşîk, Merkez-e Neşr-e Miras-e Mektub, Tahran 1378/1999, s. 174, 175. Bu ikisinden başka İhtiyar hakkında detaylı bilgi veren başka bir kaynağa ulaşılamamıştır.
} 


\section{ERTUĞRUL ÖKTEN}

biyografisi bu çevrenin anlaşılmasına da bir katkı olacaktır. Makalede ayrıca "Kadı olmak ne demek?” sorusu üzerinden kadı ve şehir ilişkisi üzerine fikir yürütülecektir. Bu soru bir şehrin sosyo-ekonomik, politik hayatını anlayabilmek için üzerine düşünülmesi gereken önemli bir sorudur.

\section{1. İhtiyar'ın Gençliği ve Kariyerinin İlk Aşamaları}

İhtiyar'ın 1491'de kaleme aldığı Esasü'l-İktibas'ta bu eseri 30'lu yaşlarda yazdığııı söylemesinden hareketle 1460 'larda doğduğu tahmin edilebilir. ${ }^{3}$ Türkçe bilmemesi İrani kökenli olduğuna işaret etmektedir. ${ }^{4}$ Hayatına dair bilinen ilk şey gençliğinde Zave'den Herat'a geldiğidir. ${ }^{5}$ Herat bu dönemde çevre şehir ve bölgelerden şairleri, hüner sahiplerini ve öğrencileri kendine çeken önemli bir çekim merkeziydi. Kaynaklar İhtiyar'ın genç iken Herat'a geldiğini söylediklerine göre o 1469'da ölen Sultan-Ebu Said devrinde değil, ondan sonra tahta geçen Sultan-Hüseyin Baykara devrinde Herat dünyasına girmiş olmalıdır. Ekberi geleneğe yakın duran Nakşibendi ve Zeynileriyle, felsefe taraftarı mehdici bir grupla ve 1470'ler ve sonrasında zaman zaman daha görünürlük kazanan Şii odaklarıyla Herat zengin bir entelektüel hayata sahipti. Eğitimini Herat’ta böyle bir ortamda alan İhtiyar'ın belli bir entelektüel pozisyonu benimsediğini eserlerinden görebilmekteyiz. ${ }^{6}$

İhtiyar'a dair bilinen diğer bir nokta da babası Gıyasüddin Türbeti'nin kadı olduğudur. ${ }^{7}$ Maalesef Gıyasüddin'in nerede kadılık yaptığını, Herat'a taşınırken İhtiyar ile beraber gelip gelmediği karanlıktır. İhtiyar'ın tespit edilebilen ilk işi Kadı Nizamüddin'in (ö. 1495) Herat’taki mahkemesinde sukuk ve sicillat yazma işiydi. ${ }^{8}$ Bu Mevlana Nizamüddin'in ölüm tarihi olan 900/1495'ten önce olmalıdır. Kadının merkezinde olduğu hukuk uygulamaları anlamına gelen kaza alanında belge düzenleme önemli bir işti ve neredeyse bir kadı kadar donanımlı ve yetenekli olmayı gerektiriyordu. Nevai Mecalisü'n-nefais'te İhtiyar'ın bu işte bilhassa iyi olduğunu söyler. ${ }^{9}$ İhtiyar'ın babasının kadı olmasının hem İhtiyar'ın kaza alanına girmesine hem de bu işte gerekli olan belge düzenleme işinde yeteneklerini geliştirmesine yardımcı olmuş olması mümkündür. Kaza alanındaki bu görev İhtiyar'ın kadılık kariyerinin habercisi olarak görülebilir. ${ }^{10}$

Nevai Mecalisü'n-Nefais'te İhtiyar'dan bahsederken şu sözleri kullanır: Nizamuddin kaza mesnedide mütemekkin irkende mahkemesi ve daru'l-kazasida sicillat ve kabalecat ve şer'iyyat anga ivrülür irdi. ${ }^{11}$ Nevai'nin burada geçmiş zaman kullanması Mecalis'in yazıldığı sırada Nizamüddin'in artık hayatta olmadığını düşündürüyor. Eğer bu doğruysa Nevai’nin İhtiyar hakkında yaptığı gözlemler Mecalis'in 1492 değil, 1498 versiyonundan geliyor olmalıdır. ${ }^{12} \mathrm{O}$ halde İhtiyar hakkında yaptığı "güzel tabiatlı ve davranışlı bir genç" gözlemi 1498 öncesinde şehirde İhtiyar'ın nasıl tanındığını gösterir.

1490'ların başında İhtiyar Timurlu çevrelerinde kendini gösterecek bazı işler yapmıştı. Bunlardan birincisi 1491'de Esasü'l-iktibas'1 yazmasıdır ki bu hayatında tarihleyebildiğimiz ilk olaydır. Eserin beyan ve inşadan bahsettiği önsözünde eserlerinde Kuran'dan alıntı (iktibas) yapmayanların aydınlıktan (nurdan) nasibi olmadığını söyledikten sonra yazdıklarına hadis, hikmet, emsalden alıntı yapmayanların dalaletten kurtulamayacaklarını ekler. ${ }^{13}$ İhtiyar'a göre beyan (ve inşa) Kuran'ı anlamanın anahtarı; i) Kuran, ii) hadis, iii) hikmetli sözler (ve şiir)den alıntı yapmak da aydınlanmanın yoludur. ${ }^{14}$ Eser saltanattan gündelik hayat seviyesine insan davranışları, değerler, vs. üzerine bu dört alandan yapılan alıntılardan oluşur. Esas önemli olan nokta bu eseri inşa ehli için Nevai'nin talep etmiş olmasıdır. O halde 1491 civarında Nevai'nin Herat'taki inşa dünyası üzerinde etkili olmaya çalıştığını iddia edilebilir ki İhtiyar da bu çabanın bir parçasıdır. ${ }^{15}$ Eseri bitirince Cami'ye takdim etmesi, Cami'nin eseri takdir edip bir takriz yazması da İhtiyar'ın bu noktada Nevai-Cami çevresinin bir üyesi olduğunu kanitlar.

\footnotetext{
${ }^{3}$ İhtiyar b. Giyasüddin, Esasü'l-İktibas, Millet Kütüphanesi, Ali Emiri, Arapça 2168, vr. 127a.

${ }^{4}$ Bahaüddin Hasan Nisari, Müzekkir-i Ahbab, haz. Seyyid Muhammed Fazlullah, Dairetü’l-Maarif, Yeni Delhi 1969, s. $22,68$.

${ }^{5}$ Günümüzdeki adı Türbet-i Haydariye olan bu şehir Meşhed'in yaklaşık 150 km. güneyindedir.

${ }^{6}$ İhtiyar'ın bu pozisyon alışında eğitiminin belirleyici bir rol oynayıp oynamadığı önemli bir sorudur ancak bu soruyu cevaplamak şu an için mümkün değildir. Medreselerin kendilerine özgü duruşları, entelektüel pozisyonları var mıydı? Duruş sahibi olduğunu bilinen Cami ve Nevai’nin kendi medreseleri vardı. Burada eğitim görenlerin Cami ve Nevai’nin fikirlerinden etkilenip onların düşünsel, siyasi kamp(lar)ına yakınlaşacakları varsayılabilir. Maalesef İhtiyar'ın hangi medreseye gittiği, Herat'taki diğer medreselerin ne tür kimliklere sahip oldukları henüz açıklığa kavuşmamış konulardır.

${ }^{7}$ Handmir, age, s. 174.

${ }^{8}$ Handmir, age, s. 174.

${ }^{9}$ Ali-şir Nevai, Mecalisü'n-Nefayis, haz. Kemal Eraslan, C. 1, TDK Yayınları, Ankara 2001, s. 142, 143.

${ }^{10}$ Fahrettin Atar, "Şürût ve sicillât”, Diyanet İslam Ansiklopedisi, C. 23, s. 271.

${ }^{11}$ Nevai, age, s. 142, 143

12 Kemal Eraslan, “Mecâlisü’n-Nefâis”, Diyanet İslam Ansiklopedisi, C. 28, Ankara 2003, s. 216.

${ }^{13}$ İhtiyar, age, vr. 2a.

14 İhtiyar, age, vr. 3b. Beyan basit tanımı ile bir anlamı değişik yollarla ifade etme sanatıdır. Ancak aşağıda görüleceği üzere kutsal anlamları insanlara ulaştıran Kuran da beyan olarak görülebilir. İşsa yazı yazma sanatı ve usulü olarak tanımlanabilir.

${ }^{15}$ Modern dönem öncesi İslam toplumunda entelektüeller, edipler, sairler, devlet görevlileri vb.nin dil vasıtası ile birbirleri ile iletișim kurması yazı ve söz imkanlarının ustalıkla kullanılmasını gerektirebiliyordu. Bu ihtiyacın inşayı ortaya çıkaran nedenlerden biri olduğu söylenebilir. 'Herat’taki inşa dünyası'ndan kasıt bu merkezde ortaya konan inşa eserleri ve faaliyetidir.
} 


\section{İHTIYAR B. GIYASÜDDIN (Ö. 928/1521): BİR TIMURLU KADISININ BIYYOGRAFİSI}

İhtiyar bundan sonra 1492 tarihinde görünür. Pay-1 Hisar Havuzu inşaatının tamamlanmasına düştüğü 897/1492 tarihi bu yıllarda şair olarak da kendisini Herat’ta kabul ettirmiş olduğunu gösteriyor. ${ }^{16}$

Görünen o ki İhtiyar'ın ünü şiirle sınırlı kalmamıştır. Nevai, yukarıda belirtildiği gibi 1498'de yazdığı Mecalis versiyonunda İhtiyar'ın Arapça ve fikıh alanında ünlü olduğunu, yeteneğinin yazdığı eserlerden anlaşıldığını, bazı eserlerinde kusur bulunup bu sebeple eleştiri aldığını söyler. ${ }^{17}$ Bu sözlerini -Kim ilim yoluna çıksa eleştirenler çok olur.- diyerek bitirir. Buradan hareketle 1490'ların sonuna doğru İhtiyar'ın Esasü'lİktibas'a ek olarak başka ilmi eserler de yazdığı sonucuna varılabilir. Maalesef eleştirilenlerin hangi eserler oldukları ve niye eleştirildikleri bilinmemektedir.

İhtiyar'ın fıkıh alanındaki yetkinliği 1500'lerde de takdir edilmiş olmalı ki kaynaklar onun zamanın meşhur fakihlerinden olduğunu ve 1506'da vefat eden Sultan-Hüseyin Baykara'nın son yıllarında Herat kadısı olduğunu söylerler. ${ }^{18}$ Kadı olarak iftayı da kapsayan çok geniş yetkileri olduğu Abdullah Mervarid'in (ö. 1541) Şerefnamesi'ne aldığı kadılığa atanma (nişan-ı kaza) dokümanından anlaşılmaktadır. ${ }^{19}$ İhtiyar bu yetkilerle Herat'ta oldukça görünür bir kişi haline gelmiş olmalıdır.

\section{Herat'ta Kadılık Meselesi}

İhtiyar'ın Herat kadılığına tayininin tam tarihi bilinmemektedir. Herat'ta kadılığı Timur öncesinden başlayarak inceleyen Manz ve Yüksel'in araştırmalarına göre Herat kadılığı uzun süre bir ailenin üyeleri tarafından üstlenildi. Kertler döneminde şehrin baş kadısı Celalüddin Mahmud el-İmami idi. Onun oğlu Kutbuddin Abdullah, Timur zamanında ve Şahruh saltanatının başında Herat kadılı̆̆ı yaptı. Kutbuddin Abdullah'ın oğlu Sadruddin Muhammed (ö. 1435) bu görevde babasının halefi oldu. Arkasından aynı göreve gelen Kutbuddin Ahmed (ö. 1474) muhtemelen Sadruddin'in yeğeni idi. O öldükten sonra da Sadruddin Muhammed'in büyük oğlu Nuruddin Muhammed (ö. 1486) bu görevi üstlendi. ${ }^{20}$ Manz’a göre bu aile Safeviler devrinde de kadılığa devam etmiştir. Manz Herat kadılarına başkalarını da ekler. Örneğin, Matlau's-Sadeyn'in yazarı Abdurrezzak Semerkandi'nin (ö. 1482) babası Celalüddin İshak Şahruh döneminin kadılarından olarak görünür. ${ }^{21}$

Bu anlatılarda ne Nevai’nin bahsettiği Kadı Nizamüddin ne de İhtiyar görünürler. Akla gelen ihtimallerden biri şehirde aynı anda birden çok kadı olabileceği ve Nizamüddin ile İhtiyar'ın bahse değer görülmemiş olmalarıdır. Ancak Herat kadılığının başka kişi/ailelerin eline geçmiş olma ihtimalini de ihmal etmemek gerekir. Görüldüğü kadarı ile Herat kadılığı üzerine biraz daha çalışılması gereken bir konudur.

\section{3. Şehri Temsil}

Maalesef bir kadı olarak İhtiyar'ın șehirde yaptıkları hakkında fazla bir bilgi yoktur. Ancak şehri temsil etme işlevine dair bazı gözlemler yapılabilir.

Vasıfi (ö. 1552) İhtiyar'ı 902/1496 tarihinde Nişabur'da ortaya çıkan ilm-i iksir ve kimya (simya) uzmanı kimyageri türlü hediyelerle Herat'a davet eden şehrin ileri gelenleri (başta Sultan-Hüseyin Baykara olmak üzere) arasında sayar. Bakır ve kalayı altın ve gümüşe çevirip değerli taşlar yapabilen ve tıp ve hikmetten de anlayan bu bilgini Herat'a girerken karşılayan şehrin ileri gelenleri arasında İhtiyar da vard. ${ }^{22}$ Vasıfi'nin bu olayı anlatırken İhtiyar'dan Kadı İhtiyar olarak bahsetmesi 1496'da İhtiyar'ın kadılık makamında olduğunu şüpheden uzak bir şekilde ispatlamasa da şehirde üstlendiği şehri/yönetimi temsil işlevinin kadılık makamına uygun bir işlev olduğu söylenebilir. Şehrin/yönetimin görünen yüzünü temsil edenler ya da şehir/yönetim adına söz söyleyebilecekler arasında artık İhtiyar da vardır.

Şaban 905/Mart 1500'de Herat Cuma Cami'sinin tamirinde eskiyen ahşap minberin mermer minberle değiştirilmesine tarih düşürme görevi İhtiyar’a verilmişti. Yapının Cuma cami olmasının ötesinde daha önce bu

\footnotetext{
${ }^{16}$ Nevai, age, s. $142,143$.

${ }^{17}$ Blochet'ye göre İhtiyar Şafii mezhebindendi. Edgar Blochet, Catalogue des manuscrits persans de la Bibliothèque nationale, C. 2. E. Leroux, Paris 1912, s. 37.

${ }^{18}$ Handmir, age, s. 174, 175.

${ }^{19}$ Hans Robert Roemer, Staatsschreiben der Timuridenzeit: das Šaraf-nāmä des 'Abdallâh Marwârî̂d in kritischer Auswertung, Franz Steiner Verlag, Wiesbaden 1952, s. 49, 38a. Timurlularda kadılık görevinin idari boyutu için bkz. Musa Şamil Yüksel, Timurlularda DinDevlet İlişkisi, TTK, Ankara 2009, s. 173, 174. Yetki alanının iftaya kadar uzanması akla İstanbul'un fethinden hemen sonra İstanbul kadısı ve müftüsü olarak atanan Hızır Bey’i (ö. 1459) getiriyor. Onun da aynı anda kaza ve ifta yetkisi olması tarihin bu devresinde İslami bürokrasilerde iki yetkinin ayrı görülmemiş olabileceği ihtimalini düşündürür. İftanın bürokratik kurumsallaşması farklı seviyelerde ortaya çıkmış görünüyor.

${ }_{20}$ Beatrice Manz, Power, Politics and Religion in Timurid Iran, Cambridge University Press, New York 2007, s. 212. Musa Şamil Yüksel, age, s. 174, 175.

${ }^{21}$ Manz, age, s. 57.

${ }^{22}$ Zeynüddin Mahmud Vasıfi, Bedayi'ü'l-Vekayi, haz. Alexander Boldrev, C. 2, İntişarat-e Bünyad-e Ferheng-e İrani, Tahran 1349/1970, s. 391, 392.
} 


\section{ERTUĞRUL ÖKTEN}

çevrede mermer bir minberin hiç görülmemiş olması bu tarih düşürmenin önemini arttırmıştır. Düşürdüğü tarihte de minberin bu özelliğini vurgulayan İhtiyar bu tarihte şair olarak da kendini Herat muhitinin kayda değer şairlerinden biri olarak kabul ettirmiş görünmektedir. ${ }^{23}$ Pay-1 Hisar Havuzu ile beraber kamusal alanda bu ikinci tarih düşürmesi olduğuna göre özellikle bu alanda yetenekli olduğunu söylenebilir. Bu tarih düşürmeler kimyageri davet olayı ile beraber düşünülürse İhtiyar'ın Herat'ın görünen yüzünü temsil ettiği yorumu güç kazanır.

\section{4. İlimde Seçkinlik}

Handmir (ö. 1535), İhtiyar'1 906/1500-01'de Nevai'nin yaptırdığı İhlasiye Medresesi’nin dört 'mütebahhir' (engin bilgi sahibi) müderrisinden biri olarak gösterir. ${ }^{24}$ Vakfiyesine göre iki müderrisi olan bu medresenin Nevai'nin öldüğü yıl olan 1501'de kadrosunun genişlemiş olması Nevai'nin Herat medrese dünyasını kontrol etme çabasının bir sonucu olmalıdır. İhtiyar da bu çabaya uygun birisidir. ${ }^{25}$

İhtiyar 908/1502‘de bazı kişilerin isteği üzerine, fikıh alanında (fetva ve şurut) iyi bilinen eserleri kullanarak Muhtarü’l-ïhtiyar ala Mezhebi'l-Muhtar adlı eserini derlemiştir. ${ }^{26}$ Yaklaşık yüz yıl sonra yazılan Müzekkir-i Ahbab'da Nisari, İhtiyar ve eseri hakkında şunları söyler: nesr ve nazm ilimlerinde güzel musannifatı vardl, bunlardan Muhtarü'l-Ihtiyar vardır ki bütün seçilmişlerin seçtiği ve bütün ileri gelenlerin tercihidir, (اختيار كل مختار و مختار كل اختيار) ve 'kadlların düsturu'l-amelidir'. ${ }^{27}$

Burada özellikle 'kadıların düsturu'l-amelidir' ifadesi çok dikkat çekicidir çünkü kadıların eseri bir referans metni olarak kullandığını ima etmektedir. İhtiyar'ın eserinin gerçekten bu statüye ulaşıp ulaşmadığını anlamak için daha fazla araştırma gerekse de elimizde 912/1506'dan bir nüshanın olması eserin kısa zaman içinde popülarite kazanmış olabileceğini düşündürüyor. ${ }^{28}$

İhtiyar'ı 1500'lerin başında müderris ve kadılıkla ilgili bir kitabın yazarı olarak görmemiz onun artı bu tarihlerde fikıh temelli daha yüksek görevlere geçtiğini, münşilik safhasının geride kaldığını düşündürüyor. Münşi iken çevre hükümdarlarla yazışmış olması ona bölgeler arası siyaset hakkında da bir fikir vermiş olmalıdır. $^{29}$

\section{Sultan-Hüseyin Baykara Sonrası}

1506 Mayıs'ında Sultan-Hüseyin Baykara öldü. Büyük oğlu Bediüzzaman Mirza (ö. 1517) ve kardeşi Muzaffer Hüseyin Mirza (ö. 1507) Timurlu geleneklerinde görülmemiş bir şekilde Herat'ta ortak sultan ilan edildilerse de Timurlu mirzaları arasındaki çekişmeler bitmedi. Mirzalar, aralarında bir uzlaşmaya varabilmek amacıyla 1506 Ekim'inde Murgab Irmağı kenarında buluştular. Buluşmaya gelen gruplardan birinin içinde İhtiyar da vard. ${ }^{30} \mathrm{Bu}$ tarihi anda İhtiyar ileride Hindistan’da Babürlü Devleti’ni kuracak olan Babür’ü (ö. 1530) ziyaret ederken görünür.

Bediüzzaman ve Babür görüştükten sonra Kadı İhtiyar, Heratlı alim Muhammed Mir Yusuf ile birlikte gelip Babür'ü ziyaret etmiști. Babür, İhtiyar'ın kimin maiyetinde olduğunu söylemese de Bediüzzaman ile görüşmesinden sonra İhtiyar'ın ziyaretinden bahsetmesi ve anlatısındaki Bediüzzaman vurgusu İhtiyar’ı ona

\footnotetext{
${ }^{23}$ Handmir, age, s. 99, 100. Bu minber günümüzde mevcut değildir. Dönemin tipik bir eğitimli Timurlu figürü olarak İhtiyar muammada da yetenekli görülüyordu, Handmir, age, s. 174, 175. 'Seçkin' değil 'kayda değer' daha uygun bir niteleme olarak gözüküyor çünkü diğer Timurlu kaynaklarında İhtiyar bir şair olarak dikkat çekmez. Akla şairlik yeteneğinin yanı sıra Nevai ile olan yakınlığının bu işi üstlenmesinde bir rol oynayıp oynamadığı geliyor. Öte yandan şair zengini Herat ortamında diğer adaylar arasında İhtiyar'ın düşürdüğü tarih güzel bulunmuş olabilir.

${ }^{24}$ Handmir, age, s. 63. Medrese kompleksi (İhlasiye) 881-86/1476-82 arasında yapılmıştı. Maria Eva Subtelny, “A Timurid Educational and Charitable Foundation: The Ikhlāșiyya Complex of 'Alī Shīr Navā' 1 in 15th-Century Herat and Its Endowment”, Journal of the American Oriental Society, C. 111, S. 1, 1991, s. 38.

${ }^{25}$ Nevai'nin Herat medreselerini kontrol etme çabası için bkz. Subtelny, agm, s. 47.

${ }^{26}$ El-Biruni Şarkşinaslık Enstitüsü (Taşkent) kataloğuna göre Muhtarü'l-İhtiyar ala Mezhebi 'l-Muhtar da alıntılardan oluşan bir derlemedir. Sobranie Vostochnykh Rukopisey Akademii Nauk Uzbekskoi CCR, C. 4, Fan, Tashkent 1998, s. 292 (Bundan sonra SVR). Anlaşılan İhtiyar için alıntı derlemeleri önemli bir eser yazma yoluydu. Eserlerinin, özellikle de Esasü'l-İktibas ve Muhtarü'l-İhtiyar'ın, daha sonraki yüzyıllarda gördüğü rağbetten İhtiyar'ın alıntı derleyerek eser oluşturma işinde oldukça başarılı olduğu anlaşılıyor.

${ }^{27}$ Nisari, age, s. 68. Bu ifadeleri Müzekkir-i Ahbab’ın bir 17. yy. nüshasında İhtiyar maddesine eklenmiş olarak görüyoruz, eseri yayına hazırlayan Fazlullah daha erken nüshalarda olmadığı söylüyor. Nisari, age, s. 68.

${ }^{28}$ SVR, C. 4, s. 292. Bu esere maalesef ulaşamadım.

${ }^{29}$ Fihristegan Nüshaha-ye Hatti-ye Iran (Fenha), haz. Mustafa Dirayeti, C. 31, Sazman-e Esnad ve Kitabhane-ye Milli-ye Cumhuri-ye İslami-ye İran, Tahran 1392/2013, s. 308 (bundan sonra Fenha). Buradaki Mekatib adlı eser İhtiyar'ın Sultan-Hüseyin Baykara adına yazdığı mektupları içerir. Bu eser gibi Münşeat-ı Hace İhtiyar adlı eser de İhtiyar mektuplarını içerir, Fenha, C. 32, s. 110. Ayrıca Münşeat, Tahran Meclis 1513'de de İhtiyar'ın bir mektubu vardır. Fenha, C. 32, s. 27. Bu eserlere de maalesef ulaşamadım. Eserleri fark etmemi sağlayan Sn. Mehmet Arıkan'a çok teşekkür ederim. Katalogdan görüldüğ̈̈ kadarı ile Münşeat, Tahran Meclis 1513, Timurlu siyasi/kültürel elitinden çok zengin malzeme içermektedir.

${ }^{30}$ Öte yandan bir şehrin kadısı ne kadar şehrin temsilcisi sıfatı ile kendi başına/şehir adına bir politik kişiliktir, ne kadar bir hükümdara tabii bir maiyet üyesidir sorusu da sorulabilir.
} 


\section{İHTIYAR B. GIYASÜDDIN (Ö. 928/1521): BİR TIMURLU KADISININ BIYYOGRAFİSI}

yakın göstermektedir. Babür Bediüzzaman’ı divanı olan güç sahibi bir hükümdar olarak anlatır. İhtiyar'ın Bediüzzaman'ın idaresi içinde olması mümkündür. ${ }^{31}$

İhtiyar-Babür buluşmasında söz Babür'ün yeni icat ettiği Babüri hattına gelmiş, İhtiyar bu hattın harflerini inceleyip kurallarını çıkarmış ve bazı yazı denemeleri yapmıştı. ${ }^{32}$ Mirzalar arasındaki esas konuşmalar gerçekleştirilip daha alt seviye görüşmeler, kişisel ziyaret ve sohbetler başladığı zaman konu hatta gelebiliyordu. ${ }^{33}$ Murgab Irmağı buluşmasında Babür'ün İhtiyar'dan kadı diye bahsetmesi onun Sultan-Hüseyin Baykara'dan sonra da kadılığa devam ettiğini akla getiriyor. İhtiyar hakkında Babür'ün gözlemleri kısa olmakla beraber onu şahsen tanıdığı için değerlidir. Babür'e göre İhtiyar Herat'ın ünlü ve zevk sahibi alimlerinden idi. ${ }^{34}$ Kadılığı iyi yapmış ve fikıh hakkında güzel bir Farsça risale yazmıştı. ${ }^{35}$

Handmir İhtiyar'ın Babür Mirza'nın hocası ve dostu olduğunu söyler. ${ }^{36}$ Halbuki Murgab Irmağı yanındaki Babür-İhtiyar görüşmesini anlatırken Babür İhtiyar'ı böyle bir pozisyonda göstermez. Bir hocalık ilişkisi kuruldu ise bunun daha sonra olmuş olması muhtemeldir.

\section{6. İhtiyar ve Şeybani Han}

İhtiyar bundan sonra Muhammed Şeybani Han'ın Herat'ı fethi sırasında karşımıza çıkar. Şeybani Han'ın 913/1507’deki fethinin hemen öncesinde Muzaffer Hüseyin Mirza’nın annesi Hadice Begim, Bediüzzaman ve Muzaffer Hüseyin Mirza için Herat ileri gelenlerinin desteğini istedi. Kadı İhtiyar da dahil olmak üzere ileri gelenler bu ikisinin iyi padişahlık yapamadıklarını Hadice Begim’e söylerken onların şahlıklarının ancak satranç tahtasındaki şahlık olduğunu ifade ettiler. Sonra Şeyhülislam Medresesi'nde kendi aralarında tartışıp şehrin anahtarlarını teslim etmeye karar verdiler. ${ }^{37}$ Bu noktada İhtiyar şehir adına karar verenler arasındadır.

Şeybani Han'ın şehre girdikten sonra ilk yapmak istediği şeylerden biri Muzaffer (Hüseyin) Mirza’nın eşi ile evlenmekti. Bu hanımın hala Muzaffer Mirza ile nikahlı olduğunu söyleyenlere karşı Kadı İhtiyar ve Mir Muhammed Emir Yusuf (yukarıda Babür'ün bahsettiği Muhammed Mir Yusuf ile aynı olmalı), Muzaffer Hüseyin Mirza'nın onu üç talak ile boşadığını ileri sürdüler. Vasıfi'ye göre bu talaktan sonra Muzaffer Hüseyin Mirza eşini tekrar nikahlamış ancak İhtiyar ve diğerleri bunu Şeybani Han’dan gizlemişlerdi. ${ }^{38}$ Burada İhtiyar'ın yeni yönetimle iş birliğine gitmeyi tercih ettiği görülüyor. Şeybani Han bu hanımla evlenmeyi çok istiyordu ve anlaşılan yönetimde söz sahibi olan Herat fukahası yeni fatihin arzuları yönünde görüş bildirmişlerdi.

İhtiyar Muhammed Şeybani Han’ın Herat fethinden sonra Herat kadısı olarak kalmış görünüyor. ${ }^{39}$ Babür yeni hanın haddini bilmediğini ve çeşitli kabul edilemez aşırılıklar sergilediğini söylerken örnek olarak cehaletine rağmen Herat' 1 meşhur ve zevk sahibi mollalarından Kadı İhtiyar ve Muhammed Mir Yusuf'a tefsir dersi vermesini gösterir. ${ }^{40}$ Bunu Şeybani Han'ın yeni bir düzen oluşturma girişimi olarak görmek isabetli olabilir. ${ }^{41}$ Yeni düzende İhtiyar ile Şeybani Han arasındaki ilişkinin iyi olduğunu gösteren bir işaret olarak Şeybani Han'ın Hezarelere karşı sefer düzenleyeceği zaman Kadı İhtiyar ve Herat şeyhülislamına bir Türkçe gazel yazıp göndermesi öne sürülebilir. ${ }^{42}$ Şeybani Han böylece şehrin kadısının ve şeyhülislamının desteğini

\footnotetext{
${ }^{31}$ Babur, Baburnâme: Babur'un hâtıratı, haz. Reşit Rahmeti Arat, C. 2, Milli Eğitim Bakanlı̆̆ı Devlet Kitapları, İstanbul 1970, s. 293 , 294.

32 Babur, age, s. 280.

${ }^{33}$ İhtiyar'ın Babüri hattını merak etmesi akla ilk olarak münşilikten gelen yazı ilgisini ilerleyen yıllarda da devam ettirdiğini getiriyor. Ancak münşilerin de iktidarı paylaştıkları/olușturdukları bu dünyada yeni bir hattın ortaya çıkıșı üzerine kapsamlı bir çalışma henüz yoktur. Bunun bir estetik iddiada bulunmak, isminden bahsettirerek propaganda yapmak gibi amaçlarının yanında belki bürokratik faydaları da (yazışma, kayıtların tutulmasında yenilik) olabilir. Sn. Selahattin Polatoğlu yeni bir yazı stili geliştirmenin uzun ömürlü, güçlü devletlerde görülebilen bir durum olduğuna, zevkte ve sanatta ulaşılan seviyeyi gösterdiğine, Abbasiler’de iki vezirin -Fadl b. Sehl (ö. 202/818) ve İbn Mukle (ö. 328/940)- yeni yazı stilleri geliştirdiğine dikkatimi çekti. Bunun için kendisine teşekkür borçluyum. Bu durumun Timurlulara uyduğu söylenebilir. Timurlular gibi kitap kültürünün çok gelişmiş olduğu bir ortamda yeni bir hattın yayılması acaba ne anlama gelirdi? İlginç bir şekilde Şeyh Hamdullah (ö. 926/1520) da Osmanlı topraklarında Babür'den az önce II. Beyazıt'ın isteği ile yeni bir yazı stili ortaya çıkarmış ve bu yazı stili yaygınlaşmıştır. Muhittin Serin, "Hamdullah Efendi, Şeyh”, Diyanet İslam Ansiklopedisi, C. 15, İstanbul 1997, s. 451. Acaba, bu arayışların ortak bir noktası var mıydı?

${ }^{34}$ Babur, age, s. 326. Babür yukarıda adı geçen Heratlı alim Muhammed Mir Yusuf'u da bu sıfatlarla betimler.

${ }^{35}$ Babur, age, s. 280.

${ }^{36}$ Handmir, age, s. 174, 175. Babur, age, s. 280, 326.

${ }^{37}$ Vasifi, age, s. 280- 282.

${ }^{38}$ Vasifi, age, s. 283.

${ }^{39}$ Handmir, age, s. 174. İhtiyar'ın Şeybani Han fethinden sonra da kadı olarak anılması için Nisari, age, s. 21, 22; Babur, age, s. 326.

${ }^{40}$ Babür Şeybani Han'ın bu tip davranışlarına Behzat'a minyatürde müdahale etmesi gibi bir örneği de eklerken Şeybani Han hakkında oldukça eleştireldir. Babur, age, s. 326.

${ }^{41}$ Fazlullah b. Ruzbihan Hunci'nin Mihmanname-i Buhara'sında Şeybani Han’ın entelektüel ilgilerine dair önemli gözlemler vardır. Şeybani Han'ın kendi eserlerinde de onun siyasi ve ahlaki düşünceleri görülür. Bunlardan hareketle Şeybani Han’a yoğunlaşan bir entelektüel tarih çalışması alanda önemli bir boşluğu doldurabilir.

${ }^{42}$ Nisari, age, s. 21.
} 


\section{ERTUĞRUL ÖKTEN}

alarak askeri harekatına meşruiyet sağlamayı amaçlamış olmalıdır. Şeybani Han'ın İhtiyar'ı önemsediği, İhtiyar Türkçe bilmediği için ona Türkçe öğretici bir eser yazmasından çıkarılabilir. ${ }^{43}$

\section{7. İhtiyar ve Safeviler}

Şeybani Han'ın Herat hakimiyeti Safevi Şah İsmail'le (ö. 1524) olan 916/1510'daki mücadeleyi kaybetmesi ile sona erdi. Bu mücadele sonucunda Şeybani Han öldü ve Herat Safevilerin eline geçti. Vasıfi şehir teslim olduktan sonra Herat Cuma Mescidi’nde Sah İsmail'in fetihnamesinin okunma sahnesini dramatik bir şekilde anlatır. ${ }^{44}$ Fetihname okunurken hazır bulunan şehrin önde gelenleri (mevali) arasında İhtiyar da vardı. Fetihnameyi Molla Cami’nin müridi olan Hafız Zeynüddin'in okumasına karar verildi. Fetihnamede sahabeye lanet eden bir bölüm olduğu için metnin kimin tarafından okunacağı önemli bir karardı. Gerçekten de korkulan oldu ve Hafız Zeynüddin metindeki sahabeye lanet satıllarını atladı. Bu noktada Herat Seyhülislam'ı Ahmed Taftazani (ö. 1510), Zeynüddin'e seslenerek kan dökülmemesi için fetihnameyi olduğu gibi okumasını söyledi. Lanet içeren satırları atlamanın karşılığında Zeynüddin minberden iner inmez bir grup Kızılbaş tarafından katledildi. Çok fazla insan toplandığı için duvarların üstünde bile insan vardı ve birkaç kişi çıkan kargaşada duvarlardan düşerek öldü. Hafız Zeynüddin'in parçalandığını gören Molla Cami'nin oğlu Ziyaüddin Yusuf kendisini kaybetti ve omuzlar üstünde dışarı çıkarıldı. Vasıfi, Şeyhülislam Ahmed Taftazani ve bazı başka ekabirin de aynı şekilde camiden çıkarıldığını söyler.

Vasıfi İhtiyar'ın katil sahnesinde olduğunu söyler ancak İhtiyar'ın tepkilerine dair herhangi bir bilgi vermez. Tepkisini bildiğimiz üç kişiden ikisi, Hafız Zeynüddin ve Ziyaüddin Yusuf yeni durumu kaldıramamıș, Herat şeyhülislamı ise politik davranmayı bilmişti. İhtiyar'ın tepkilerinin görülmemesi belki de şeyhülislam gibi politik davranarak şehir halkının güvenliğini öncelemek, yani yine bir yerde şehri temsil etmek ile ilgili olabilir miydi? Eğer böyleyse İhtiyar bu pozisyonunu kısa zaman içinde kaybetmiş görünüyor. Buna kanıt olarak bir hami arayışına geçip Babür'e Ahlak-ı Hümayun adlı eserini ithaf ederken eserin önsözünde -yüz hile ile katilden kurtulduğunu, büyük ailesinin perişan olduğunu, çareyi inzivaya çekilip meşayih ruhlarına teveccühte bulduğunu- söylemesi verilebilir. ${ }^{45}$

Blochet İhtiyar'ın Timurluların 16. yy'ın bașındaki çöküşünden sonra 920/1514 yılında Sultan-Hüseyin Baykara'nın oğlu Bediüzzaman Mirza ile beraber İstanbul'a gelmiş olabileceğini söyler. ${ }^{46}$ Heyecan verici bir ihtimal olmakla beraber böyle bir ziyarete başka bir kaynakta değinilmemiştir.

Ahlak-ı Hümayun'un yazılması İhtiyar'ın hayatına dair bildiğimiz son şeylerden biridir. Bu eserde İhtiyar değindiği konuları çok sayıda tablo ile olağanüstü sistematik bir halde sunar. ${ }^{47} \mathrm{Bu}$ sistematik yaklaşım Esasü'lÍktibas'ta da hemen fark edilir. İçerik açısından birbirine yakın olan bu iki eser aynı zamanda sağlam bir iç organizasyon anlayışını paylaşırlar ki buradan hareketle İhtiyar'ın oldukça sistematik bir zihne sahip olduğu söylenebilir.

Eserin ithafı ve tarihlendirmesi konusu tartışmalıdır. Alam eserin ilk versiyonunun Sultan-Ebu Said zamanında henüz genç bir mirza olan Sultan-Hüseyin Baykara için yazıldığını söyler. ${ }^{48}$ Sultan-Ebu Said zamanında İhtiyar çok genç olduğu için bu zor gözüküyor. M. Ekber Aşîk’e göre ise İhtiyar bu eseri 912/150607 'de yazmıştı. ${ }^{49}$ Eserin başlığı Babür'ün oğlu Hümayun’a bir ithafin söz konusu olabileceğini düşündürse de bunu destekleyecek bir işarete rastlanmamıştır.

\section{Zave'ye Dönüş}

Eser ne zaman yazılmış olursa olsun yazarın önsözdeki sözleri İhtiyar'ın 1510'larda Afganistan coğrafyasındaki Timurilerle şansını denediğini gösteriyor. Ancak İhtiyar'ın hayatının sonunda memleketi olan Zave'ye çekildiği bilinmektedir. Neden Babür çevresinde kalmadığına dair henüz bir açıklama yoktur. Herat’a uzanan yolun başında bulunması sebebi ile Türkmenler, Timurlular, Afganlar gibi birçok grubun zaman zaman

\footnotetext{
${ }^{43}$ Nisari, age, s. 22

${ }^{44}$ Vasifi, age, s. 248, 249.

45 İhtiyar b. Gıyasüddin, Ahlak-ı Hümayun, Bibliothèque nationale de France, Département des Manuscrits, Supplément Persan 266, Gallica. https://gallic a.bnf.fr/ark:/12148/btv1b60012688?rk=21459;2, 18.10.2020 09:40, 4b.

${ }^{46}$ Blochet, age, s. 37. Blochet'ye göre İhtiyar Babürlülerin kurucusu olan Zahirüddin Babür’e ithaf ettiği Ahlak-ı Hümayun adlı eserinin bir başka versiyonunu Desturü'l-Vizare adıyla Osmanlı hükümdarı I. Selim’e ithaf etmişti. Blochet, age, s. 37, katalog no. 767. İhtiyar Ahlak-ı Hümayun'u çevresindeki insanların isteği üzerine hükümdarların hallerini anlatan bir eser olmak üzere daha önce bu konuda yazılmıs olan belli başlı eserlerden özetle 912/1506 yılında yazmıştır. Desturü’l-Vizare adıyla Sultan Selim’e ithaf edilen nüsha 926/1520 tarihlidir. Blochet, age, s. 38, katalog no. 768.

${ }^{47} \mathrm{Bu}$ hali ile eserin pedagojik bir amaca hizmet ettiği de akla gelmektedir.

${ }^{48}$ Muzaffar Alam, “A Muslim State in a non-Muslim context: the Mughal Case”, Mirror for the Muslim Prince, haz. Mehrzad Bourujerdi. Syracuse University Press, Syracuse, NY 2013, s. 171, 172.

${ }^{49}$ Handmir, age, s. 174, 175. Muzaffer Alam ise eserin Tusi’nin Ahlak-ı Nasirisi’nin Sultan-Hüseyn Baykara'nın isteği üzerine yazılan iki uyarlamasından biri olduğunu söylüyor. Alam’a göre diğer uyarlama da Hüseyin Vaiz-i Kaşifi'nin Ahlak-ı Muhsinisi idi. Alam, age, s. 171.
} 


\section{İHTIYAR B. GIYASÜDDIN (Ö. 928/1521): BİR TIMURLU KADISININ BIYYOGRAFİSí}

kontrol etmeye çalıştığı Zave 1510’larda daha ziyade Safevi etki alanı içinde kalmıştır. Bu sebeple İhtiyar'ın Şah İsmail'e ithaf ettiği söylenen Adl u Cevr isimli mesnevisi onun bu döneme ait eseri olabilir. ${ }^{50}$ Sam Mirza'ya (ö. 1532) göre hayatının sonlarına doğru yazdığı beş bin beytlik bu mesnevi Sadi’nin (ö. 1292) Bostan ve Gülistanı'nı örnek alarak yazılmıştı. ${ }^{51}$ Şah İsmail'i 'Şeh-i Hızır-rey-i Sikender-zamir / Feridun-ilm-i Husrev-i Cem-serir' diyerek överken İhtiyar'ın hedefi Safevi hakimiyetindeki topraklarda tepki çekmeden kalabilmek olmalıdır. ${ }^{52}$ Hedefine ulaşmış olmalı ki İhtiyar 928/1521-2 yılında Zave'de vefat etti ve oradaki aile mezarlığına gömüldü. ${ }^{53}$

\section{9. İhtiyar'ın Ailesinin Devamı}

İhtiyar'ın evlatları arasında en dikkat çekeni büyük oğlu Emir Muhammed Bed‘i’l-kadı'dır. Emir Muhammed, Nisari’nin Müzekkir-i Ahbab'ına almaya layık göreceği kadar iyi bir şair, kadı olabilecek kadar donanımlı bir alim ve yetenekli bir idareciydi. Nisari'nin Emir Muhammed'in uzun yıllar Herat'ta kadılık yaptığını, sultanlar ve hakanların onu kendisine uygun yüksek mevkilere getirmekte gecikmediklerini söylemesi akla 1500’lerin ilk yarısında Herat Safevi (sultan?) ve Özbek (hakan?) yönetimleri arasında el değiştirirken Emir Muhammed'in pozisyonunu korumayı başardığını düşündürür. İhtiyar'ın büyük ailesi bir noktada perişan olsa da en azından oğullarından birinin yüksek statü sahibi bir alime uygun bir şekilde yetişmiş olduğunu söylenebilir. ${ }^{54}$ İhtiyar hayatının sonunda köşesine çekilmiş olsa bile aile geleneği ve itibarının devam ettiği, Herat'ta unutulmadıkları da iddia edilebilir. Bu aynı zamanda İran dünyasında gördüğümüz belirli makamların aynı ailelerin elinde kalması uygulamasının bir başka örneğidir.

\section{Eserler}

İhtiyar'ın eserleri şunlardır: Esasü’l-İktibas, Ahlak-ı Hümayun, Zinetü’l-Libas, Şerh-i Kaside-i Cami, Muhtar el-İhtiyar, İktibasat, Adl u Cevr, Münşeat-ı Hace Ihtiyar, Şerh-i Mukaddimeti's-Salat ve bazı fikh risaleleri. ${ }^{55}$ Bunlardan Muhtar el-Ihtiyar, İktibasat, Adl u Cevr ve fikh risalelerine ulaşamadık.

\section{SONUÇ}

Bu makale İhtiyar'ın Timurlu dünyasında başlayıp Safevilere kadar uzanan hayatının ana hatlarını tespite çalışmıştır. İhtiyar'ın biyografisine ek olarak öne çıkan bulgular şunlardır: Bir kadı olarak İhtiyar'ın şehrin temsilcisidir. İhtiyar ve oğlunun Herat'ta kadılık yapmalarından hareketle Timurlu-Özbek-Safevi geçişinde bürokratik devamlılığın söz konusu olduğu, yeni yönetimlerin iş başına gelmesi ile şehrin bürokratik yapısının baştan aşağıya değişmediği ileri sürülebilir.

Kadı, şehir ve İhtiyar'ın pozisyonunun devamlılığını bir arada değerlendirince ilk bakışta görünmeyen bir tarihi aktör daha öne çıkar: şehir halkı. Değişen iktidarlara rağmen İhtiyar'ın pozisyonunu korumasının bir nedeninin şehir halkının kendini desteklemesi olduğu düşünülebilir. Safevi fetihnamesinin okunması sahnesinde İhtiyar'ın tepkisiz gözükerek kan dökmek istemeyen tarafa yakın görünmesi onun 'idare-i maslahat' becerisine ve bu yeteneği ile şehir halkının da menfaatlerini kollama endişesine işaret ediyor olabilir. Ömrünün sonunda artık Safevi toprağı olan Zave'ye dönmesi de idare-i maslahatta yetenekli olmasına bir kanıt olarak sunulabilir. Ayrıca, İhtiyar'ın şehirle olan ilişkisini düşünmeye başlayınca Herat kadısının başka şehirlerdeki kadılara göre daha güçlü bir konumda olduğu iddia edilebilir. Şehri Şeybani Han’a teslim tartışmalarında Timurlu tarafını desteklemek isteyen Hadice Begim'e verdiği cevap, sonraki teslim tartışmalarındaki rolü bu güçlü konumu destekler.

\footnotetext{
${ }^{50}$ Sam Mirza, Tuhfe-i Sami, haz. Vahid Destgiri, Matbaa-ye Armagan, Tahran 1314/1935, s. 31.

${ }^{51}$ Sam Mirza, age, s. 30, 31. M. Ekber Aşîk bu eseri 909-911/1503-05 arasına tarihlendirir ki bu noktada Timurlu çöküşüne henüz birkaç y1l vardır. Bu durumda, eğer Şah İsmail'e ithaf edilen daha geç bir nüsha yoksa ya Şah İsmail'e ithaf ya da tarihlendirme problemlidir. Handmir, age, s. 175. Maalesef eseri görmek mümkün olmadı.

${ }^{5}$ Sam Mirza, age, s. 30, 31.

${ }^{53}$ Simsar, agm, s. 174.

${ }^{54}$ Nisari, age, s. 407. Nisari Emir Muhammed Bed‘i’l-kadı’nın birçok ilimde güzel ve rağbet edilen eseri olduğunu söyler. İhtiyar’ın biyografisini araştırmaya devam etmek için bu eserleri incelemek bir yol olabilir. Sultan, hakan arasında bir derece farkı olması da mümkündür: Siret-e Celaladdin'e göre Harzemşahlarda hakan sultandan daha üstündü. Şihabüddin Muhammed Hurendizi Zeyderi Nesevi, Siret-e Celalüddin, haz. Mücteba Minuvi, Şirket-e İntişarat-e İlmi ve Ferhengi, Tahran 1384/2005, s. $281,282$.

${ }^{55}$ Handmir, age, s. 174, 175. Blochet, age, s. 37. Simsar, agm, s. 174, 175. Şerh-i Kaside-yi Cami için Sam Mirza ve Nisari bu eserin doğru adının Muhtarü'l-Envar olduğunu söylerler. Sam Mirza, age, s. 31; Nisari, age, 68. Münşeat için bkz. Münşeat-l Hace İhtiyar, Tahran, Saltanati, s. 100. Münşeat, Tahran, Meclis, 1513’te de İhtiyar'ın mektupları vardır. Bu eserlerden yalnızca Esasü’l-İktibas basılmıştır: ElHüseyn b. Gıyasüddin el-Hüseyni İhtiyarüddin el-Herevi, Esasü’l-İktibas fi'l-Belaga ve'l-İnşa, haz. Nasır Muhammedi Muhammed Cad, Darü’l-Meyman, Riyad 2018.
} 


\section{ERTUĞRUL ÖKTEN}

\section{KAYNAKÇA}

ALAM, Muzaffar, “A Muslim State in a non-Muslim context: the Mughal Case”, Mirror for the Muslim Prince, haz. Mehrzad Bourujerdi, Syracuse University Press, Syracuse, New York 2013, ss. 160-189.

ATAR, Fahrettin, "Şürût ve sicillât”, Diyanet İslam Ansiklopedisi, C. 39, İstanbul 2010, ss. 270-273.

BABUR, Baburnâme: Babur'un hâttratı, haz. Reşit Rahmeti Arat, C. 2, Milli Eğitim Bakanlığı Devlet Kitapları, İstanbul 1970. 1912.

BLOCHET, Edgar, Catalogue des manuscrits persans de la Bibliothèque nationale, C. 2, E. Leroux, Paris

ERASLAN, Kemal, “Mecâlisü’n-Nefâis”, Diyanet İslam Ansiklopedisi, C. 28, Ankara 2003, ss. 216-217.

Fihristegan Nüshaha-ye Hatti-ye Iran (Fenha), ed. Mustafa Dirayeti, C. 31, Sazman-e Esnad ve Kitabhane-ye Milli-ye Cumhuri-ye İslami-ye İran, Tahran 1392/2013.

HANDMIR, Gıyasüddin b. Himamüddin, Mekarimu'l-Ahlak Şerh-e Ahval u Zindegani-ye Emir Alişir Nevai, haz. Muhammed Ekber Aşîk, Merkez-e Neşr-e Miras-e Mektub, Tahran 1378/1999.

İHTIYAR b. GIYASÜDDIN, Ahlak-ı Hümayun, Bibliothèque nationale de France, Département des Manuscrits, Supplément Persan 266, Gallica, https://gallica.bnf.fr/ark:/12148/btv1b60012688?rk=21459;2 18.10.2020 sa. 09:40.

İHTIYAR b. GIYASÜDDİN, Esasü'l-İktibas, Millet Kütüphanesi, Ali Emiri, Arapça 2168. 2007.

MANZ, Beatrice. Power, Politics and Religion in Timurid Iran, Cambridge University Press, New York

NESEVI, Şihabüddin Muhammed Hurendizi Zeyderi, Siret-e Celalüddin, haz. Mücteba Minuvi, Şirket-e İntişarat-e İlmi ve Ferhengi, Tahran 1384/2005.

NEVAİ, Ali-şir, Mecalisü’n-Nefayis, haz. Kemal Eraslan, C. 1, TDK Yayınları, Ankara 2001.

NISARİ, Bahaüddin Hasan, Müzekkir-i Ahbab, haz. Seyyid Muhammed Fazlullah, Dairetü'l-Maarif, Yeni Delhi 1969.

ROEMER, Hans Robert, Staatsschreiben der Timuridenzeit: das Šaraf-nāmä des 'Abdallâh Marwâriîd in kritischer Auswertung, Franz Steiner Verlag, Wiesbaden 1952.

SAM MIRZA, Tuhfe-i Sami, haz. Vahid Destgiri, Matbaa-ye Armagan, Tahran 1314/1935. 452.

SERIN, Muhittin, "Hamdullah Efendi, Şeyh", Diyanet İslam Ansiklopedisi, C. 15, İstanbul 1997, ss. 449-

SIMSAR, Muhammed Hasan, "İhtiyarüddin Türbeti”, Daire-ye Bozorg-e Maarif-e İslami, C. 7, Tahran 1377/1998, ss. 174, 175.

Sobranie vostochnykh rukopisey Akademii Nauk Uzbekskoi CCR, C. 4, Fan, Tashkent 1998.

SUBTELNY, Maria Eva, "A Timurid Educational and Charitable Foundation: The Ikhlāșiyya Complex of "Alī Shīr Navā'ì in 15th-Century Herat and Its Endowment", Journal of the American Oriental Society, C. 111, S. 1, 1991, ss. 38-61.

VASIFI, Zeynüddin Mahmud, Bedayi'ü'l-Vekayi, ed. Alexander Boldrev, C. 2, İntişarat-e Bünyad-e Ferheng-e İrani, Tahran 1349/1970.

WOODS, John E., The Timurid Dynasty, Indiana University, Bloomington Indiana 1990.

YÜKSEL, Musa Şamil, Timurlularda Din-Devlet İlişkisi, TTK, Ankara 2009. 
İHTIYYR B. GIYASÜDDIN (Ö. 928/1521): BİR TIMMURLU KADISININ BIYYOGRAFİSİ 